\title{
THE RELATION BETWEEN DARK ADAPTATION AND THE LEVEL OF VITAMIN A IN THE BLOOD
}

\author{
By CHARLES HAIG AND ARTHUR J. PATEK, JR. \\ (From the Research Service, First Medical Division, Welfare Hospital, Department of \\ Hospitals, New York City, and the Department of Medicine, College of \\ Physicians and Surgeons, Columbia University, New York City)
}

(Received for publication December 29, 1941)

The purpose of the present study is to determine if a relation exists between dark adaptation measurements and the level of vitamin $A$ and total carotenoids in the blood plasma, in normal subjects and in patients with cirrhosis of the liver.

It has been established that the retina's ability to adapt to the dark depends upon an adequate supply of vitamin A from the diet. The evidence has been reviewed by Wald and his co-workers (1), and by Hecht and Mandelbaum (2). Although failures to observe any influence of vitamin A intake upon dark adaptation have been recorded ( 3 to 5 ), other studies of experimental vitamin $\mathrm{A}$ deficiency $(1,2,6$ to 10$)$ have shown that the visual threshold at complete dark adaptation can be elevated greatly by reduced vitamin A intake. In the latter studies the rate of dark adaptation remained unaltered.

It has been shown previously (11 to 15$)$ that patients with cirrhosis of the liver may have greatly delayed dark adaptation, with or without elevation of the final threshold. Since in these patients the response to vitamin A therapy was characterized by an increase in the rate of dark adaptation and a decrease in the final threshold (when originally high), it was concluded that there exists in cirrhosis of the liver a disturbance of vitamin A metabolism which differs from ordinary vitamin A deficiency.

It also has been shown that low values for vitamin $A$ are found in the plasma and liver of experimental animals with vitamin A deficiency $(16,17)$. Moreover, the livers of rats with carbon tetrachloride cirrhosis have been shown to contain only half the amount of vitamin A present in the livers of normal animals fed the same quantity of food and of vitamin A (18). Likewise, in patients with cirrhosis of the liver, low values for vitamin $\mathrm{A}$ are found in both the circulating plasma (19 to 22) and in the liver tissue at autopsy (22 to 26). Since both dark adaptation and the level of plasma vitamin A are related directly to the state of nutrition with reference to vitamin A, it seemed reasonable to expect a degree of correlation between the two types of measurement.

\section{METHODS}

The apparatus and the technique here employed for measuring the dark adaptation function have been described elsewhere $(12,27,28)$. The intensity of the white pre-adapting light was 6,000 millilamberts, and was viewed by the subject with the right eye for 3 minutes. The test light, a flash of 0.2 second duration, passed through a violet filter (Corning No. 511). The retinal region tested was a circular area whose diameter subtended a $2^{\circ}$ visual angle and was located $5^{\circ}$ nasally to the fovea of the right eye of the subject. Both the preadapting light and the test flash were viewed through a $2 \mathrm{~mm}$. artificial pupil placed at a distance of $3 \mathrm{~mm}$. before the cornea of the subject.

The plasma level of vitamin A and total carotenoids were determined by a modification of the method described by Kimble (29). It was found that shaking the plasma sample for 15 minutes with the ethanol before adding petroleum ether insured more complete precipitation of the proteins and more thorough extraction of the vitamin $\mathrm{A}$ and carotenoids. It was also discovered that using the chloroform and the antimony trichloride solution at a low temperature (circa $10^{\circ} \mathrm{C}$.) delays the development and fading of the blue color of the vitamin $\mathrm{A}-\mathrm{SbCl}_{\mathbf{3}}$ reaction sufficiently to permit several readings before the maximum density is attained and passed, thus making possible a more exact estimate of the maximum value. The densities were measured in a Bausch and Lomb spectrophotometer. The vitamin A and carotenoid levels were expressed as international units (I.U.) and micrograms $(\mu \mathrm{gm}$.$) , respectively, per 100 \mathrm{ml}$. of plasma. Whenever a sufficient quantity of plasma was available, duplicate determinations were made.

All of the patients received highly nutritious diets which were estimated from food tables (30) to provide at least 13,000 I.U. of vitamin A daily. None had fever, jaundice, or diarrhea at the time the tests were made. The observed abnormal values, therefore, are not attributable to low intake of the vitamin, to fever, nor to faulty gastrointestinal absorption due to jaundice or diarrhea. 


\section{RESULTS}

In Figure 1 are plotted the upper and lower limits of the data of 60 individual dark adaptation tests made on 37 normal persons between the ages of 20 and 45 years. The abscissae are minutes in the dark after cessation of light adaptation, and the ordinates are the logarithms of the threshold intensities expressed in micromicrolamberts ( $\mu \mu \mathrm{l}$.). The final threshold is the lowest threshold reading obtained during a stay in the dark sufficiently long to define the entire rod function. The adaptation time is defined as the number of minutes in the dark required for the dark adaptation function to attain a threshold level of 5.50. This parameter obviously possesses both velocity and threshold-level dimensions, and thus serves as an over-all index of the subject's dark adaptation status.

Values for the adaptation time and for the final threshold of the 37 normal persons are given in Table I. When more than one observation was made on an individual, the mean value is given, and the number of observations indicated in parentheses. The adaptation time ranges in value from an average of 9.5 mniutes to $\mathbf{1 5 . 0}$ minutes, with a mean of 13.1 minutes. The final threshold values range from an average of 3.95 to 4.42 , with a mean of 4.20. For unexplained reasons the values for a single individual may vary in exceptional cases by as much as 3 minutes and $0.4 \mathrm{log}$ unit over a period of several months. However, the usual limits of change over a period of 2 or 3 weeks are approximately \pm 0.5 minute and $\pm 0.2 \log$ unit.

Within the age limits studied, neither sex nor age appear to exert a significant influence upon either the adaptation time or the final threshold.

The plasma vitamin A values found in Table I are based upon 74 measurements on 44 normal persons between the ages of 20 and 45 years. The values range from 109 to 309 I.U. per cent and have a mean value of 198 I.U. per cent. The amount of variation in single individuals over a period of months may be almost as great as the individual differences shown in the table. Changes as great as $\mathbf{5 0}$ per cent have been observed within a period of only one week. This instability of the vitamin A blood level presents a striking contrast to the relative constancy of the dark adaptation function. It is accounted for in part

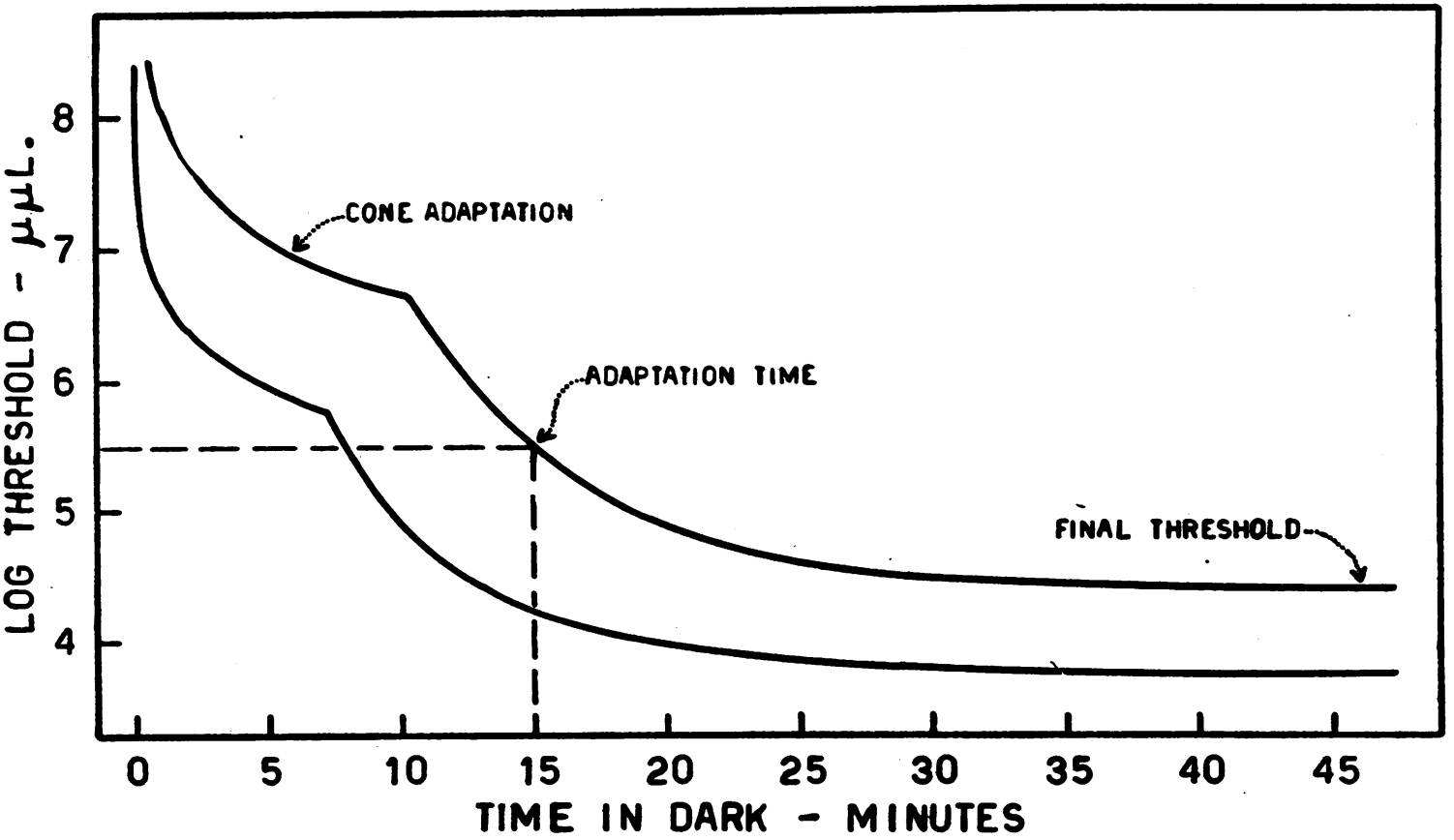

Fig. 1. The Limits of 60 Dark Adaptation Measurements in 37 Normal Subjects Average values of the parameters designated adaptation time and final threshold for each subject are recorded in Table I. 
TABLE I

Plasma vitamin A, plasma carotenoids, dark adaptation time, and final threshold intensity in normal persons (When the value represents an average, the number of observations is indicated in parentheses.)

\begin{tabular}{|c|c|c|c|c|c|c|c|c|c|}
\hline \multicolumn{5}{|c|}{ Males } & \multicolumn{5}{|c|}{ Females } \\
\hline Subject & $\underset{\text { vitamin A }}{\text { Plasma }}$ & $\begin{array}{c}\text { Plasma } \\
\text { carotenoids }\end{array}$ & $\begin{array}{c}\text { Adaptation } \\
\text { time }\end{array}$ & $\begin{array}{c}\text { Final } \\
\text { threshold }\end{array}$ & Subject & $\underset{\text { vitamin A }}{\text { Plasma }}$ & $\left|\begin{array}{c}\text { Plasma } \\
\text { Carotenoids }\end{array}\right|$ & $\underset{\text { Adaptation }}{\text { time }}$ & $\underset{\text { threshold }}{\text { Final }}$ \\
\hline $\begin{array}{l}1 \mathrm{M} \\
2 \mathrm{M} \\
3 \mathrm{M} \\
4 \mathrm{M} \\
5 \mathrm{M} \\
6 \mathrm{M} \\
7 \mathrm{M} \\
8 \mathrm{M} \\
9 \mathrm{M} \\
10 \mathrm{M} \\
11 \mathrm{M} \\
12 \mathrm{M} \\
13 \mathrm{M} \\
14 \mathrm{M} \\
15 \mathrm{M} \\
16 \mathrm{M} \\
17 \mathrm{M} \\
18 \mathrm{M} \\
19 \mathrm{M} \\
20 \mathrm{M} \\
21 \mathrm{M} \\
22 \mathrm{M} \\
23 \mathrm{M} \\
24 \mathrm{M} \\
25 \mathrm{M} \\
26 \mathrm{M} \\
27 \mathrm{M} \\
28 \mathrm{M} \\
29 \mathrm{M} \\
30 \mathrm{M} \\
31 \mathrm{M}\end{array}$ & $\begin{array}{l}1 . U . \text { per } \\
100 \mathrm{ml} \\
189(7) \\
197(4) \\
205(7) \\
180(2) \\
193(2) \\
159 \\
260(2) \\
309 \\
109 \\
229 \\
149(2) \\
209(2) \\
167 \\
285 \\
230 \\
280 \\
214 \\
290(2) \\
267 \\
230 \\
192 \\
169\end{array}$ & $\begin{array}{l}\text { Mgm. per } \\
100 \text { ml. } \\
140(7) \\
150(4) \\
185(7) \\
106(2) \\
117(2) \\
174 \\
69(2) \\
146(2) \\
122 \\
91 \\
143(2) \\
94(2) \\
234 \\
149 \\
108 \\
216 \\
158 \\
260(2) \\
112 \\
203 \\
183 \\
183\end{array}$ & $\begin{array}{l}\text { minutes } \\
9.5(3) \\
11.3(3) \\
15.0(2) \\
14.2 \\
12.4(2) \\
10.7 \\
14.0 \\
13.0 \\
12.2(2) \\
12.5 \\
13.8 \\
12.3(2) \\
14.9 \\
\\
12.8 \\
\\
10.8 \\
14.3 \\
12.9(2) \\
15.0 \\
13.6 \\
12.0(2) \\
14.3 \\
13.8 \\
9.7 \\
13.5\end{array}$ & $\begin{array}{l}\text { log } \mathrm{mel} \text {. } \\
4.18(3) \\
4.02(3) \\
4.29(2) \\
4.30 \\
4.25(2) \\
4.00 \\
4.40 \\
4.00 \\
4.13(2) \\
4.30 \\
4.00 \\
4.39(2) \\
4.42 \\
\\
4.20 \\
\\
4.25 \\
4.10 \\
4.20(2) \\
4.42 \\
4.42 \\
4.08(2) \\
4.20 \\
4.25 \\
4.20 \\
4.20\end{array}$ & $\begin{array}{r}1 \mathrm{~F} \\
2 \mathrm{~F} \\
3 \mathrm{~F} \\
4 \mathrm{~F} \\
5 \mathrm{~F} \\
6 \mathrm{~F} \\
7 \mathrm{~F} \\
8 \mathrm{~F} \\
9 \mathrm{~F} \\
10 \mathrm{~F} \\
11 \mathrm{~F} \\
12 \mathrm{~F} \\
13 \mathrm{~F} \\
14 \mathrm{~F} \\
15 \mathrm{~F} \\
16 \mathrm{~F} \\
17 \mathrm{~F} \\
18 \mathrm{~F} \\
19 \mathrm{~F} \\
20 \mathrm{~F} \\
21 \mathrm{~F} \\
22 \mathrm{~F} \\
23 \mathrm{~F}\end{array}$ & $\begin{array}{l}1 . U \text { per } \\
100 \text { ml. } \\
149(2) \\
176(2) \\
213 \\
135 \\
172(3) \\
273 \\
186(2) \\
144 \\
198 \\
176 \\
195 \\
158(3) \\
213 \\
265 \\
125 \\
125 \\
141 \\
282 \\
114 \\
192\end{array}$ & $\begin{array}{l}\text { agm. per } \\
100 \mathrm{ml} . \\
106(2) \\
156(2) \\
104 \\
113 \\
110(3) \\
174(2) \\
135(2) \\
129 \\
133 \\
158 \\
154 \\
245(3) \\
125 \\
108 \\
166 \\
133 \\
154 \\
239 \\
75 \\
108\end{array}$ & $\begin{array}{l}\text { minutes } \\
12.0(3) \\
13.0(2) \\
14.9(2) \\
11.8 \\
10.9(4) \\
15.0 \\
\\
14.2 \\
13.6\end{array}$ & $\begin{array}{l}\text { log } \mu \mathrm{\mu l} . \\
4.03(3) \\
3.97(2) \\
4.15(2) \\
4.10 \\
4.10(4) \\
4.40\end{array}$ \\
\hline $\begin{array}{l}\text { Mean } \\
\text { Standard deviation }\end{array}$ & $\begin{array}{r}212 \\
49.8\end{array}$ & $\begin{array}{l}146 \\
46.9\end{array}$ & $\begin{array}{l}12.9 \\
1.65\end{array}$ & $\begin{array}{l}4.22 \\
0.132\end{array}$ & $\begin{array}{l}\text { Mean } \\
\text { Standard } \\
\text { deviation }\end{array}$ & $\begin{array}{l}182 \\
28.3\end{array}$ & $\begin{array}{r}142 \\
27.4\end{array}$ & $\begin{array}{r}13.4 \\
1.23\end{array}$ & $\begin{array}{l}4.15 \\
0.198\end{array}$ \\
\hline $\begin{array}{l}\text { Mean of } M+F \\
\text { Standard deviation }\end{array}$ & $\begin{array}{c}198 \\
41.5\end{array}$ & $\begin{array}{c}144 \\
34.8\end{array}$ & $\begin{array}{l}13.1 \\
1.57\end{array}$ & $\begin{array}{l}4.20 \\
0.142\end{array}$ & & & & & \\
\hline
\end{tabular}

by a seasonal variation, possibly correlated with diet (31). However, so many departures from the seasonal trend have been noted, that, almost certainly, one or more additional unknown factors must exert an influence upon the level of vitamin $\mathrm{A}$ in the blood.

The difference of 30 I.U. per cent between the mean values for men and for women in the plasma vitamin A data of Table $I$ is found to have statistical significance. This confirms similar findings by Kimble (29) and by Murrill and his co-workers (32). On the other hand, the mean plasma carotenoid levels of the two sexes are practically identical, which contrasts with the findings of Kimble and of Murrill et al. of slightly higher values for women than for men.

Within the age limits studied, no significant influence of age upon the plasma vitamin $\mathrm{A}$ and carotenoid levels was observed. ${ }^{1}$

I In another study (33), by a procedure which was calibrated against the present technique, the mean level of vitamin $A$ in the blood of infants between 3 weeks and 6 months of age was found to be 74 I.U. per cent, that for infants between 6 and 18 months of age 110 I.U. per cent, and that for children from 6 to 12 years of age 117 I.U. per cent. When the mean of 198 I.U. per cent here obtained on adult subjects is added to this series, it is apparent that the level of plasma vitamin A rises significantly with increasing age up to the adult level. 
For studying the relation between the two kinds of measurement, blood for vitamin $\mathrm{A}$ and carotenoid analysis was drawn on the same day that the dark adaptation tests were made. Table II presents 67 such simultaneous dark adaptation plasma measurements in 14 normal persons, 18 persons with cirrhosis of the liver, and 7 persons with various other chronic diseases. Figure 2

TABLE II

Simultaneous measurements of plasma vitamin $A$ and carotenoids, and of dark adaptation

\begin{tabular}{|c|c|c|c|c|c|c|}
\hline $\begin{array}{l}\text { Sub- } \\
\text { ject }\end{array}$ & Sex & Diagnosis & $\begin{array}{c}\text { Plasma } \\
\text { vita- } \\
\text { min A }\end{array}$ & $\begin{array}{l}\text { Plasma } \\
\text { carote- } \\
\text { noids }\end{array}$ & $\begin{array}{c}\text { Adap- } \\
\text { tation } \\
\text { time }\end{array}$ & $\begin{array}{l}\text { Final } \\
\text { thres- } \\
\text { hold }\end{array}$ \\
\hline & & & $\left|\begin{array}{l}1 . U . \mathrm{per} \\
100 \mathrm{ml} .\end{array}\right|$ & $\begin{array}{l}\text { Mgm. per } \\
100 \mathrm{ml} .\end{array}$ & $\begin{array}{l}\text { min- } \\
\text { ules }\end{array}$ & $\log \mu \mu l$. \\
\hline $\begin{array}{l}1 \mathrm{M} \\
1 \mathrm{M}\end{array}$ & $\begin{array}{l}\mathbf{M} \\
\mathbf{M}\end{array}$ & $\begin{array}{l}\text { Normal } \\
\text { Normal }\end{array}$ & $\begin{array}{l}256 \\
142\end{array}$ & $\begin{array}{l}116 \\
134\end{array}$ & $\begin{array}{l}8.5 \\
7.8\end{array}$ & $\begin{array}{l}4.10 \\
4.00\end{array}$ \\
\hline $2 \mathrm{M}$ & $\mathbf{M}$ & Normal & 175 & 170 & 10.8 & 3.95 \\
\hline $2 \mathrm{M}$ & $M$ & Normal & 204 & 129 & 11.5 & 4.05 \\
\hline 3M & $M$ & Normal & 218 & 176 & 15.0 & 4.42 \\
\hline $\begin{array}{l}\text { 13M } \\
19 M\end{array}$ & $\begin{array}{l}\mathbf{M} \\
\mathbf{M}\end{array}$ & $\begin{array}{l}\text { Normal } \\
\text { Normal }\end{array}$ & $\begin{array}{l}167 \\
267\end{array}$ & $\begin{array}{l}234 \\
112\end{array}$ & $\begin{array}{l}12.5 \\
12.8\end{array}$ & $\begin{array}{l}4.30 \\
4.20\end{array}$ \\
\hline $22 \mathrm{M}$ & $M$ & Normal & 169 & 183 & 10.8 & 4.25 \\
\hline 30M & $M$ & Normal & 180 & 64 & 9.7 & 4.20 \\
\hline $31 \mathrm{M}$ & $\mathbf{M}$ & Normal & 200 & 83 & 13.5 & 4.20 \\
\hline$\frac{1 F}{2 F}$ & $\mathbf{F}$ & $\begin{array}{l}\text { Normal } \\
\text { Normal }\end{array}$ & $\begin{array}{l}181 \\
137\end{array}$ & $\begin{array}{l}149 \\
133\end{array}$ & $\begin{array}{r}9.9 \\
12.5\end{array}$ & $\begin{array}{l}4.05 \\
3.84\end{array}$ \\
\hline $5 F$ & $\mathbf{F}$ & Normal & 141 & 96 & 10.9 & 4.10 \\
\hline $5 \mathbf{F}$ & $\mathbf{F}$ & Normal & 189 & 83 & 10.9 & 4.10 \\
\hline $7 F$ & $\mathbf{F}$ & Normal & 134 & 111 & 15.0 & 4.40 \\
\hline $\begin{array}{l}19 \mathrm{~F} \\
20 \mathrm{~F}\end{array}$ & F & Normal & $\begin{array}{l}114 \\
192\end{array}$ & $\begin{array}{r}75 \\
108\end{array}$ & $\begin{array}{l}11.3 \\
13.6\end{array}$ & $\begin{array}{l}4.25 \\
4.10\end{array}$ \\
\hline $3 \mathrm{C}$ & $\mathbf{M}$ & $\begin{array}{l}\text { Cirrhosis of the } \\
\text { liver }\end{array}$ & 122 & 116 & 23.5 & 4.89 \\
\hline $3 \mathrm{C}$ & $\mathbf{M}$ & $\begin{array}{l}\text { Cirrhosis of the } \\
\text { liver }\end{array}$ & 146 & 125 & 16.5 & 4.25 \\
\hline $3 \mathrm{C}$ & $\mathbf{M}$ & Cirrhosis of the & 161 & 134 & 21.5 & 4.40 \\
\hline $3 C$ & $\mathbf{M}$ & Cirrhosis of the & 192 & 212 & 21.0. & 4.60 \\
\hline $3 \mathrm{C}$ & $\mathbf{M}$ & Cirrhosis of the & 147 & 141 & 22.8 & 4.55 \\
\hline $3 \mathrm{C}$ & $\mathbf{M}$ & Cirrhosis of the & 75 & 174 & 23.8 & 4.50 \\
\hline & & liver & & & & \\
\hline $3 \mathrm{C}$ & $\mathbf{M}$ & $\begin{array}{l}\text { Cirrhosis of the } \\
\text { liver }\end{array}$ & 90 & 224 & 23.0 & 4.30 \\
\hline $3 C$ & $\mathbf{M}$ & Cirrhosis of the & 106 & 241 & 22.5 & 4.95 \\
\hline $3 \mathrm{C}$ & $\mathbf{M}$ & Cirrhosis of the & 85 & 220 & 19.7 & 3.90 \\
\hline $3 C$ & $\mathbf{M}$ & Cirrhosis of the & 180 & 133 & 20.7 & 4.30 \\
\hline $3 \mathrm{C}$ & $\mathbf{M}$ & Cirrhosis of the & 98 & 116 & 18.9 & 3.90 \\
\hline & & & & & & \\
\hline $3 \mathrm{C}$ & $\mathbf{M}$ & $\begin{array}{l}\text { Cirrhosis of the } \\
\text { liver }\end{array}$ & 193 & 187 & 18.7 & 3.30 \\
\hline $6 \mathrm{C}$ & $\mathbf{M}$ & $\begin{array}{l}\text { Cirrhosis of the } \\
\text { liver }\end{array}$ & 105 & 215 & 14.3 & 4.50 \\
\hline $9 \mathrm{C}$ & $\mathbf{M}$ & $\begin{array}{l}\text { Cirrhosis of the } \\
\text { liver }\end{array}$ & 116 & 145 & 16.2 & 4.70 \\
\hline $12 \mathrm{C}$ & $\mathbf{F}$ & $\begin{array}{l}\text { Cirrhosis of the } \\
\text { liver }\end{array}$ & 24 & 216 & 18.2 & 4.20 \\
\hline $12 \mathrm{C}$ & $\mathbf{F}$ & $\begin{array}{l}\text { Cirrhosis of the } \\
\text { liver }\end{array}$ & 74 & 73 & 25.0 & 4.25 \\
\hline $15 \mathrm{C}$ & $F$ & $\begin{array}{l}\text { Cirrhosis of the } \\
\text { liver }\end{array}$ & 32 & 125 & 29.0 & 4.75 \\
\hline
\end{tabular}

TABLE II-Continued

\begin{tabular}{|c|c|c|c|c|c|c|}
\hline $\begin{array}{l}\text { Sub- } \\
\text { ject }\end{array}$ & Sex & Diagnosis & $\begin{array}{c}\text { Plasma } \\
\text { vita- } \\
\text { min A }\end{array}$ & $\begin{array}{l}\text { Plasma } \\
\text { carote- } \\
\text { noids }\end{array}$ & $\begin{array}{c}\text { Adap- } \\
\text { tation } \\
\text { time }\end{array}$ & $\begin{array}{l}\text { Final } \\
\text { thres- } \\
\text { hold }\end{array}$ \\
\hline & & & $\left|\begin{array}{l}1 . U . \mathrm{per} \\
1.00 \mathrm{ml} .\end{array}\right|$ & $\begin{array}{l}\mu \mathrm{gm} . \mathrm{per} \\
100 \mathrm{ml} .\end{array}$ & $\underset{\text { min- }}{\min }$ & $\log \mu \mu l$. \\
\hline $15 C$ & $\mathbf{F}$ & $\begin{array}{l}\text { Cirrhosis of the } \\
\text { liver }\end{array}$ & 47 & 133 & 26.5 & 4.20 \\
\hline $16 C$ & $\mathbf{F}$ & $\begin{array}{l}\text { Cirrhosis of the } \\
\text { liver }\end{array}$ & 62 & 291 & 21.8 & 4.25 \\
\hline $16 \mathrm{C}$ & $\mathbf{F}$ & $\begin{array}{l}\text { Cirrhosis of the } \\
\text { liver }\end{array}$ & 100 & 179 & 19.8 & 4.40 \\
\hline $16 C$ & F & $\begin{array}{l}\text { Cirrhosis of the } \\
\text { liver }\end{array}$ & 63 & 270 & 17.0 & 4.40 \\
\hline $33 \mathrm{C}$ & F & $\begin{array}{l}\text { Cirrhosis of the } \\
\text { liver }\end{array}$ & 161 & 66 & 12.5 & 4.00 \\
\hline $36 C$ & $\mathbf{M}$ & $\begin{array}{l}\text { Cirrhosis of the } \\
\text { liver }\end{array}$ & 47 & 135 & 19.0 & 4.10 \\
\hline $36 \mathrm{C}$ & $\mathbf{M}$ & $\begin{array}{l}\text { Cirrhosis of the } \\
\text { liver }\end{array}$ & 49 & 91 & 17.5 & 4.20 \\
\hline $36 \mathrm{C}$ & $\mathbf{M}$ & $\begin{array}{l}\text { Cirrhosis of the } \\
\text { liver }\end{array}$ & 44 & 83 & 19.4 & 4.25 \\
\hline $37 C$ & F & $\begin{array}{l}\text { Cirrhosis of the } \\
\text { liver }\end{array}$ & 93 & 166 & 14.5 & 4.80 \\
\hline $37 C$ & F & $\begin{array}{l}\text { Cirrhosis of the } \\
\text { liver }\end{array}$ & 27 & 66 & 14.0 & 5.00 \\
\hline $54 C$ & $\mathbf{M}$ & $\begin{array}{l}\text { Cirrhosis of the } \\
\text { liver }\end{array}$ & 57 & 58 & 18.0 & 4.30 \\
\hline $54 \mathrm{C}$ & $\mathbf{M}$ & $\begin{array}{l}\text { Cirrhosis of the } \\
\text { liver }\end{array}$ & 60 & 57 & 19.4 & 4.50 \\
\hline $55 \mathrm{C}$ & $\mathbf{M}$ & $\begin{array}{l}\text { Cirrhosis of the } \\
\text { liver }\end{array}$ & 87 & 44 & 15.1 & 4.10 \\
\hline $56 \mathrm{C}$ & $\mathbf{F}$ & $\begin{array}{l}\text { Cirrhosis of the } \\
\text { liver }\end{array}$ & 116 & 44 & 25.0 & 4.90 \\
\hline $57 \mathrm{C}$ & $\mathbf{M}$ & $\begin{array}{l}\text { Cirrhosis of the } \\
\text { liver }\end{array}$ & 164 & 79 & 10.4 & 4.50 \\
\hline $58 \mathrm{C}$ & $\mathbf{F}$ & $\begin{array}{l}\text { Cirrhosis of the } \\
\text { liver }\end{array}$ & 85 & 42 & 18.8 & 4.24 \\
\hline $59 \mathrm{C}$ & $\mathbf{F}$ & $\begin{array}{l}\text { Cirrhosis of the } \\
\text { liver }\end{array}$ & 77 & 36 & 21.0 & 4.40 \\
\hline $61 C$ & F & $\begin{array}{l}\text { Cirrhosis of the } \\
\text { liver }\end{array}$ & 98 & 40 & 24.0 & 4.90 \\
\hline $62 C$ & $\mathbf{M}$ & $\begin{array}{l}\text { Cirrhosis of the } \\
\text { liver }\end{array}$ & 89 & 50 & 12.5 & 4.40 \\
\hline $63 C$ & $\mathbf{M}$ & $\begin{array}{l}\text { Cirrhosis of the } \\
\text { liver }\end{array}$ & 69 & 28 & 13.1 & 4.30 \\
\hline $\begin{array}{r}9 \mathrm{H} \\
9 \mathrm{H} \\
11 \mathrm{H} \\
27 \mathrm{H} \\
27 \mathrm{H} \\
27 \mathrm{H} \\
52 \mathrm{H} \\
52 \mathrm{H} \\
52 \mathrm{H} \\
52 \mathrm{H} \\
53 \mathrm{H} \\
54 \mathrm{H} \\
71 \mathrm{H}\end{array}$ & $\begin{array}{l}\mathbf{F} \\
\mathbf{F} \\
\mathbf{F} \\
\mathbf{F} \\
\mathbf{F} \\
\mathbf{F} \\
\mathbf{F} \\
\mathbf{F} \\
\mathbf{F} \\
\mathbf{F} \\
\mathbf{F} \\
\mathbf{M}\end{array}$ & $\begin{array}{l}\text { Nephrosis } \\
\text { Nephrosis } \\
\text { Diabetes mellitus } \\
\text { Urolithiasis } \\
\text { Urolithiasis } \\
\text { Urolithiasis } \\
\text { Hyperthyroidism } \\
\text { Hyperthyroidism } \\
\text { Hyperthyroidism } \\
\text { Hyperthyroidism } \\
\text { Myxedema } \\
\text { Myxedema } \\
\text { Anomalous portal } \\
\text { vein }\end{array}$ & $\begin{array}{r}122 \\
152 \\
199 \\
84 \\
105 \\
107 \\
155 \\
173 \\
133 \\
162 \\
116 \\
170 \\
166\end{array}$ & $\begin{array}{r}191 \\
187 \\
170 \\
97 \\
56 \\
71 \\
75 \\
58 \\
37 \\
50 \\
145 \\
133 \\
179\end{array}$ & $\begin{array}{r}9.0 \\
13.7 \\
16.7 \\
21.3 \\
25.0 \\
23.2 \\
17.7 \\
15.5 \\
13.3 \\
14.5 \\
13.0 \\
16.1 \\
14.8\end{array}$ & $\begin{array}{l}3.95 \\
4.05 \\
4.40 \\
4.40 \\
4.35 \\
4.35 \\
4.25 \\
4.10 \\
3.67 \\
4.10 \\
4.16 \\
4.50 \\
4.50\end{array}$ \\
\hline
\end{tabular}

shows the relation of the plasma vitamin $A$ values to $(A)$ the dark adaptation time, and to $(B)$ the final threshold.

\section{DISCUSSION}

When the several groups of subjects are regarded as a single population, the data of Figure 2 show that the higher dark adaptation values 

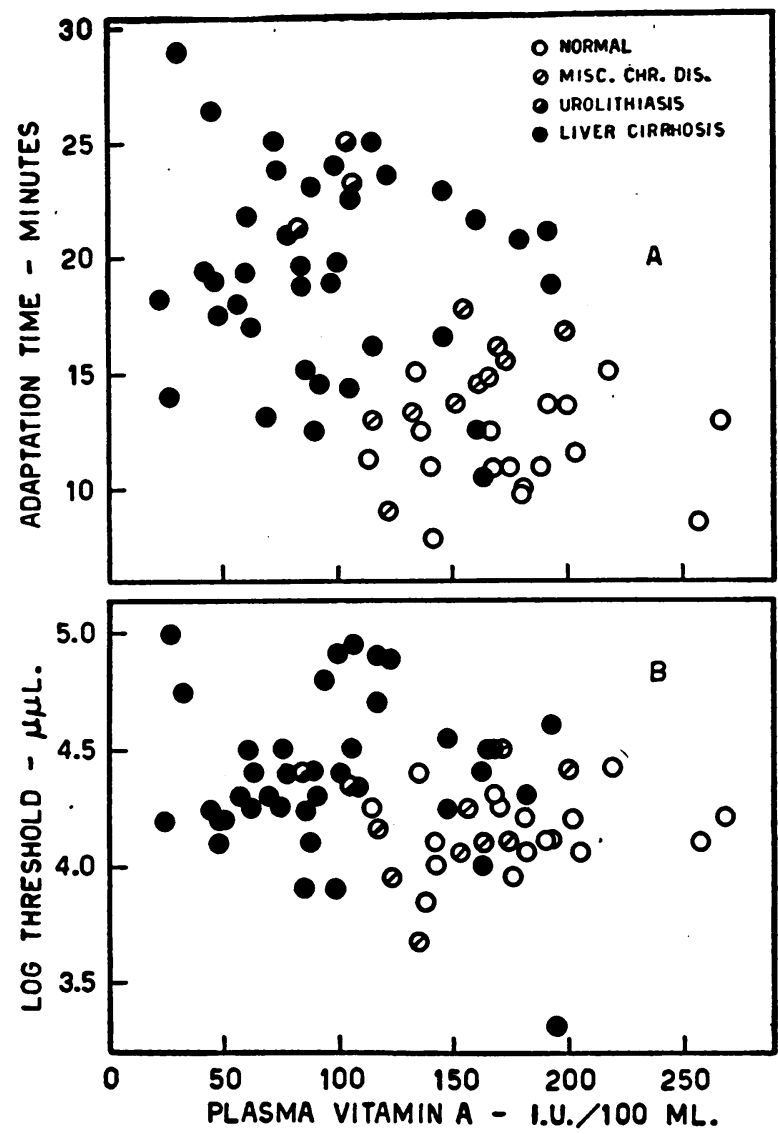

Fig. 2. Relation of the Plasma Vitamin A Level to $(A)$ The Dark adaptation Time, and to $(B)$ The Logarith of the Final Threshold Intensity

The 67 points represent individual observations made on the same days in 14 normal persons, 18 patients with cirrhosis of the liver, and 7 patients with certain other diseases. Note that the data representing the several clinical categories are not randomly distributed with relation to each other, but are crudely aligned in the order: liver cirrhosis, urolithiasis, miscellaneous chronic diseases, and normal.

tend to be associated with the lower vitamin $\mathrm{A}$ values, suggesting a degree of correlation between the two variables. This effect is more marked in Figure $2 A$ (adaptation time) than in Figure $2 B$ (final threshold). When, however, the data of the cirrhotic and normal groups in this figure are regarded separately as distinct populations, they show an essentially random distribution. Within either of these clinical categories, therefore, no correlation is apparent between the plasma vitamin A level and either parameter of the dark adaptation function.
Since the data of the several groups are not randomly distributed over the same range of values, it is apparent that the correlations arise from a tendency of the data to group themselves according to the separate clinical categories, the cirrhotics being at one end of a series and the normals at the other. This tendency for patients with cirrhosis of the liver to have higher dark adaptation and lower plasma vitamin $\mathrm{A}$ values than normal controls has been previously observed (22). However, in the previous study the dark adaptation and vitamin $A$ values were not measured simultaneously.

Similar correlations between dark adaptation measurements and the plasma vitamin A level have been reported previously by others. It is possible that these correlations, like those of the present data, are attributable to other factors rather than to a direct dependence of the retina upon the level of vitamin $A$ in the blood. In the studies by Lindqvist (20), Pett and LePage (34), and Lewis et al. (33), heterogeneous groups of patients (miscellaneous diseases) were also employed. In that by Josephs and his co-workers (35), the subjects were drawn from four different nutritional categories as determined by questionnaires and by economic status.

Evidence that the retinal supply of vitamin A may be largely independent of the level of the vitamin in the blood is provided by the observations of Lewis and his co-workers (36), who found that the retinas of rats on a diet of low vitamin $A$ content retained a maximal quantity of vitamin A, although the plasma level had dropped to an extremely low value. Even more striking is the finding that thyroid extract or a-dinitrophenol administered to patients with delayed dark adaptation, not only lowered the plasma vitamin $\mathrm{A}$ and carotenoid levels, but simultaneously increased the speed and extent of dark adaptation (37). Still other factors, enumerated in an earlier report (22), have been shown to influence independently either the dark adaptation or the blood vitamin A level. It nevertheless appears reasonable, when known complicating factors are excluded, to regard dark adaptation values as measures of the utilization of vitamin $A$ by the retina. The level of vitamin $A$ in the blood, on the other hand, has been shown ex- 
perimentally to be an index of the amount of the vitamin stored in the liver $(16,17)$. Thus, the two types of measurement probably record quantitative variations in two quite different aspects of vitamin A metabolism.

\section{SUMMARY}

Measurements of dark adaptation upon 37 normal persons revealed no sex differential. In determinations of the plasma vitamin $\mathrm{A}$ and total carotenoid levels in 44 normal persons, the mean vitamin A level for the women was found to be 14 per cent lower than that for the men, while the mean carotenoid levels were the same in the two sexes.

Sixty-seven simultaneous dark adaptation and plasma vitamin $\mathrm{A}$ and carotenoid measurements were obtained in 14 normal persons, 18 persons with cirrhosis of the liver, and 7 persons with various other chronic diseases. Within the cirrhotic and normal groups, separately considered, no significant correlations were observed between the plasma vitamin A or the plasma carotenoid levels and the dark adaptation values. When all of the normal and abnormal subjects were grouped together as a single population, however, a degree of correlation between the dark adaptation measurements and the vitamin $A$ values became apparent. This relation was interpreted as arising from differences peculiar to the several diagnostic groups studied, rather than from a causal relation between the level of vitamin $A$ in the blood and the rate and extent of dark adaptation.

\section{BIBLIOGRAPHY}

1. Wald, G., Jeghers, H., and Arminio, J., An experiment in human dietary night blindness. Am. J. Physiol., 1938, 123, 732.

2. Hecht, S., and Mandelbaum, J., Dark adaptation and experimental human vitamin A deficiency. Am. J. Physiol., 1940, 130, 651.

3. Steffens, L. F., Bair, H. L., and Sheard, C., Photometric measurements on visual adaptation in normal adults on diets deficient in vitamin A. Proc. Staff Meet., Mayo Clin., 1939, 14, 698.

4. Steininger, G., Roberts, L. J., and Brenner, S., Vita$\min \mathbf{A}$ in the blood of normal adults. J. A. M. A., 1939, 113, 2381.

5. Isaacs, B. L., Jung, F. T., and Ivy, A. C., Clinical studies of vitamin A deficiency. Arch. Ophth., $1940,24,698$.
6. Jeghers, $H$., The degree and prevalence of vitamin $A$ deficiency in adults. J. A. M. A., 1937, 109, 756.

7. Booher, L. E., and Callison, E. C., The minimum vitamin-A requirements of normal adults. J. Nutrition, 1939, 18, 459.

8. Jeans, P. C., Blanchard, E. L., and Satterthwaite, F. E., Dark adaptation and vitamin A. J. Pediat., 1941, 18, 170.

9. Haig, C., and Lewis, J. M., Simple method of measuring brightness threshold of dark adapted eye at all ages. Proc. Soc. Exper. Biol. and Med., 1939, 41, 415.

10. Lewis, J. M., and Haig, C., Vitamin A requirements in infancy as determined by dark adaptation. $\mathrm{J}$. Pediat., 1939, 15, 812.

11. Haig, C., Hecht, S., and Patek, A. J., Jr., Vitamin A and rod-cone dark adaptation in cirrhosis of the liver. Science, 1938, 87, 534.

12. Patek, A. J., Jr., and Haig, C., The occurrence of abnormal dark adaptation and its relation to vitamin A metabolism in patients with cirrhosis of the liver. J. Clin. Invest., 1939, 18, 609.

13. Zaffke, K. H., Hemeralopie als Symptom bei Thyreotoxikosen und Lebererkrankungen. Deutsches Arch. f. klin. Med., 1939, 183, 433.

14. Wohl, M. G., and Feldman, J. B., Vitamin A deficiency in diseases of liver. J. Lab. and Clin. Med., 1940, 25, 485.

15. Bajardi, G., and Galeone, A., La cecità notturna quale sintomo di malattia epatica. Policlinico (sez. prat.), 1941, 48, 193.

16. Lewis, J. M., Bodansky, O., Falk, K. G., and McGuire, G., Relationship of vitamin A blood level in the rat to vitamin $A$ intake and to liver storage. Proc. Soc. Exper. Biol. and Med., 1941, 46, 248.

17. Horton, P. B., Murrill, W. A., and Curtis, A. C., Vitamin $A$ and carotene. I. The determination of vitamin $A$ in the blood and liver as an index of vitamin A nutrition of the rat. J. Clin. Invest., 1941, 20, 387.

18. Haig, C., and Post, J., Vitamin A concentration in rat liver during recovery from $\mathrm{CCl}_{4}$ cirrhosis. Proc. Soc. Exper. Biol. and Med., 1941, 48, 710.

19. Lasch, F., Uber den Vitamin A-Spiegel im Blute bei Leberkrankheiten. Klin. Wchnschr., 1938, 17, 1107.

20. Lindqvist, T., Studien über das Vitamin $\mathbf{A}$ beim Menschen. Acta med. Scand., 1938, Supp. 97, pp. $1-262 ; 1-52$.

21. Rubegni, $\mathbf{R}$., Il contenuto in vitamin $\mathbf{A}$ e in carotina del siero umano in varie condizioni pathologiche. Policlinico (sez. med.), 1939, 46, 565.

22. Haig, C., and Patek, A. J., Jr., Vitamin A deficiency in Laennec's cirrhosis. The relative significance of the plasma vitamin $A$ and carotenoid levels and of the dark adaptation time. J. Clin. Invest., 1942, 21, 309.

23. Moore, T., Vitamin A and carotene: The vitamin A reserve of the adult human being in health and disease. Biochem. J., 1937, 31, 155. 
24. Breusch, F., and Scalabrino, R., Die quantitativen Verhältnisse der Leberlipoide. Ztschr. f. d. ges. exper. Med., 1934, 94, 569.

25. Woo, T. T., and Chu, F. T., Vitamin A content of livers of Chinese infants, children and adults. Chinese J. Physiol., 1940, 15, 83.

26. Ralli, E. P., Papper, E., Paley, K., and Bauman, E., The vitamin $A$ and carotene content of human liver in normal and in diseased subjects. Arch. Int. Med., 1941, 68, 102.

27. Hecht, S., and Shlaer, S., An adaptometer for measuring human dark adaptation. J. Optic. Soc. America, 1938, 28, 269.

28. Haig, C., The course of rod dark adaptation as influenced by the intensity and duration of preadaptation to light. J. Gen. Physiol., 1941, 24, 736.

29. Kimble, M. S., The photocolorimetric determination of vitamin $\mathrm{A}$ and carotene in human plasma. J. Lab. and Clin. Med., 1939, 24, 1055.

30. Daniel, E. P., and Munsell, H. E., Vitamin A Content of Foods. U. S. Dept. of Agric. misc. publ. 275, June, 1937.

31. Catel, W., Klinische und tierexperimentelle Studien über die normale und pathologische Physiologie des A-Vitamins. Monatschr. f. Kinderh., 1938, 73, 316.

32. Murrill, W. A., Horton, P. B., Leiberman, E., and Newburgh, L. H., Vitamin A and carotene. II. Vitamin $A$ and carotene metabolism in diabetics and normals. J. Clin. Invest., 1941, 20, 395.

33. Lewis, J. M., Bodansky, O., and Haig, C., Level of vitamin $A$ in the blood as an index of vitamin $A$ deficiency in infants and in children. Am. J. Dis. Child., 1941, 62, 1129.

34. Pett, L. B., and LePage, G. A., Vitamin A deficiency. III. Blood analysis correlated with a visual test. J. Biol. Chem., 1940, 132, 585.

35. Josephs, H. W., Baber, M., and Conn, H., Studies in vitamin A. Bull. Johns Hopkins Hosp., 1941, 68, 375.

36. Lewis, J. M., Bodansky, O., Falk, K. G., and McGuire, G., Vitamin A requirements in the rat. J. Nutrition, 1942, 23, 351.

37. Patek, A. J., Jr., and Haig, C., Effect of administration of thyroid extract and of $\alpha$-dinitrophenol upon dark adaptation. Proc. Soc. Exper. Biol. and Med., 1941, 46, 180. 